\title{
Prospects of African Integration in Light of the Theory of Optimum Currency Areas
}

\author{
Július Horváth \\ Southern Illinois University and CERGE-EI, Prague
}

Richard Grabowski

Southern Illinois University

\begin{abstract}
This paper empirically addresses the question of the prospects of integration among African states in light of M undell's theory of optimum currency areas. The symmetry and asymmetry of shocks affecting A frican countries is measured by a structural vector autoregression decomposition method developed by Blan chard and Quah [1989] and Bayoumi and Eichengreen [1992]. The results indicate that the scope for such integration is quite limited. Asymmetry of supply shocks prevails throughout Africa and especially in its Eastern part. On the other hand, we found that there are groups of countries in Northern Africa, Western Africa and Southern Africa which share symmetric demand shocks. (JEL Classification: F 36, 055)
\end{abstract}

\section{Introduction}

In the beginning of the next century the world economy may be divided 
nations, a yen block in East Asia, and a dollar-block in North America. This integration effort is likely to create pressures for integration in various regions of the less developed world, including Africa.

Efforts at integration within Africa are nothing new. After independence a number of different schemes have been proposed to span much of Africa in a cooperative framework. However, the involvement, willingly or unwillingly, of Africa in the Cold War, the fear of political domination by stronger states, and differences in the level of economic development have made it difficult to achieve significant economic cooperation at the all-Africa level. Consequently, efforts at regional integration within Africa have received priority. Currently in Africa there are at least eleven economic communities of one type or another. ${ }^{1}$ Besides these organizations there are numerous intergovernmental agencies seeking cooperation on a wide variety of issues.

Despite all of the above efforts aimed at integration, these economic communities, for the most part, "exist only on paper."2 This paper will be concerned with examining the potential for integration within the context of the theory of optimum currency areas. In other words, do conditions within Africa warrant the formation of regional currency areas or an all-A frican currency area? Although such currency unions represent a form of integration which seems well beyond the political capabilities of some African governments, this may not be true in the future. ${ }^{3}$ In addition, it will shed light on whether fixed or flexible exchange rates are more appropriate among African nations in general and among nations within various regional subgroups within Africa.

Of course, any sort of monetary union will involve some loss of sovereignty over certain aspects of economic policy. Some macroeconomic decision making would be made at the level of the union rather than the individual country. Thus many African leaders are reluctant to lose control over 
etary union in the African context, see Cobham and Robson [1994].

The paper is organized as follows. In section two the optimum currency literature is discussed with an emphasis on how the character of shocks can affect the integration process. Section three will briefly discuss the econometric methodology which is based on a special decomposition of structural vector autoregressive models. Section four will present the estimation results while section five will provide conclusions and a summary.

\section{Theoretical Background}

In this study the symmetry or asymmetry of different exogenous shocks affecting various African regions and all Africa is used as a criteria to determine the desirability of currency unions. It can be seen as an empirical application of an approach defined in the literature on optimum currency areas which stresses the characteristics that would make countries better or worse candidates for currency union. However, in a broader sense it is an investigation into the nature and sources of exogenous disturbances affecting particular groups of African countries. In this broader sense this study seeks to determine whether flexible or fixed exchange rates should be used by policy makers to insulate the country from these shocks. ${ }^{4}$ In this section optimum currency area theor $\mathrm{y}^{5}$ is briefly examined with emphasis on the

4. It is sometimes argued that the less developed countries of Africa do not really face the choice of having independently floating exchange rates. M cKinnon [1979] raises the point that limitations on the flow of capital, restrained capital markets, and the small size of the foreign exchange market could lead for most of these countries only to one question: to what currency to peg 〈see also Devarajan and de M elo [1987]). On the other hand, in recent years one can observe a move towards liberalization of exchange rate systems in some African countries with the move toward more market determined exchanae rates 〈IM F [19941. D. 26〉. 
question of shocks affecting a particular area.

M undell [1961] in his seminal paper asked the question "what is an appropriate domain of an optimum currency area?" He proposed an answer suggesting that there could be constraints to the size of the currency area, depending on the character of shocks affecting the economy. M undell argued that in situations of sticky wages and prices and low factor mobility, ${ }^{6}$ country-specific shocks could have severe consequences on real variables if the adjustment power of nominal exchange rates cannot be used. Thus the evaluation of the costs of joining a currency union (having irrevocably fixed exchange rates among different countries or having only one currency for different countries) is, in the spirit of M undell's argument, connected with the identification of the character of shocks affecting a given area. $M$ undell's argument sends the following warning: if shocks affecting countries are symmetric (affecting each country in a similar way) then joining a currency union (fixed exchange rates) will not constrain, since for symmetric shocks an overall union response will suffice. If, on the other hand, the shocks are mainly asymmetric then an over-all response could be, for some countries, very costly.

shocks, while a highly diversified economy can form an area in a fixed exchange rate system. Other studies stressed the mutual closeness of potential member countries in terms of institutions and economic policies. For excellent surveys see Ishiyama [1975] and Tavlas [1993]. For all practical purposes we need to agree with M achlup [1977, p.71] that "what ultimately counts, however, is that all members are willing to give up their independence in matters of money, credit, and interest. Pragmatically, therefore, an optimum currency area is a region no part of which insists on creating money and having a monetary policy of its own."

6. M undell [1961] observed that factor mobility should play a crucial role in determining the boundaries of currency areas. In currency areas factors should be mobile, while among currency areas labor and capital should be immobile. In the context of ... 
Approaching the questions of currency areas through investigating the character of shocks affecting different areas was used in the early nineties in the empirically oriented literature concerning the future of the European M onetary Union 〈B ayoumi and Eichengreen 1992, Chamie et. al. 1994, and Whitt 1995). Although B ofinger [1994] argued that M undell's one-country, one sector model is hardly adequate to describe highly diversified European economies, it would seem an adequate description of many less developed countries. Thus this paper extends the technique to analyze whether Africa, or certain regions within Africa, are territories where country specific, idiosyncratic shocks prevail or territories where shocks affect all countries in a rather similar way. The problem is what types of shocks are affecting certain groups of countries and how can they be identified.

There is no unique proper method to address this problem. One way of approaching it is to try to identify different types of exogenous shocks of the same character for different countries. Working directly with observed data on real output or any other macro variable does not, however, allow us to distinguish exogenous disturbances from policy responses to these disturbances. Observed movements in real GDP reflect the combined effects of shocks and responses. ${ }^{8}$ Thus a methodology should be used which could clearly, however not uniquely, distinguish between the movement of disturbances affecting macrovariables and the movement of the macrovariables themselves. Such a methodology was proposed by Bayoumi and Eichengreen [1992] in terms of a vector autoregressive system based on identification as developed by Blanchard and Quah [1989].

\section{Methodology}

The methodology is based on the familiar aggregate demand (AD) and 
and price. ${ }^{9}$ The formal analysis carried out below is within this context.

Consider two types of orthogonal shocks that are the sources of variation in domestic output, $\mathrm{y}_{\mathrm{t}}$, and the price level, $\mathrm{p}_{\mathrm{t}}$ : a supply shock, $¥_{1 \mathrm{t}}$, and a demand shock, $¥_{2 t}$. Following Bayoumi and Eichengreen [1992] we identify them as real supply (having a permanent effect on real output) and nominal demand shocks (having only a temporary effect on real output). ${ }^{10}$ Assuming the variables are unit root processes ${ }^{11}$ and are in logarithms, the vector $\Delta \mathrm{X}_{\mathrm{t}}=\left[\Delta \mathrm{y}_{\mathrm{t}} \Delta \mathrm{p}_{\mathrm{t}}\right]$ is stationary and can be written as an infinite moving average process:

$$
\Delta \mathrm{X}_{\mathrm{t}}=\sum_{\mathrm{i}=0}^{\infty} \mathrm{A}_{\mathrm{i}} \mathrm{t}-\mathrm{i}=\mathrm{A}(\mathrm{L})_{\mathrm{t}}
$$

or

$$
\left[\begin{array}{l}
\Delta y_{t} \\
\Delta p_{t}
\end{array}\right]=\left[\begin{array}{l}
a_{11}(L) a_{12}(L) \\
a_{21}(L) a_{22}(L)
\end{array}\right]\left[\begin{array}{l}
1 t \\
2 t
\end{array}\right]
$$

where $a_{i j}(L)$ are polynomials and $A_{i}$ are matrices in the lag operator $L$. The time paths of the effects of various shocks on the growth rate of output and

9. M asson and Taylor [1994, p. 35] classify shocks according to the criteria of symmetry (symmetric or asymmetric), or origin (foreign or domestic), and according to their time impact (permanent or temporary). The analysis of this paper does not distinguish between domestic and foreign shocks.

10. The decomposition of macro variables to their permanent and temporary part is carried out in studies by Nelson and B everidge [1982] in univariate and by Vahid and Engle [1993] in a multivariate framework. In this approach it is assumed that the permanent part follows a random walk, while the transitory part is stationary. As discussed later, we base our analysis on the decomposition suggested by Blanchard and Quah [1989]. They do not make any assumption about whether the permanent $\ldots \ldots+c \ldots$. 
prices are given by the coefficients of the polynomials $a_{i j}(L)$. F urthermore, coefficient $a_{i j}(k)$ in the $a_{i j}(L)$ polynomial is the response of variable $i$ to $a$ unit shock in $¥_{i t}$ after $k$ periods. We also adopt the notation such that $a_{i j}(1)$ is the sum of all the moving average coefficients and gives the cumulative effect of $¥_{\mathrm{jt}}$ on variable $\mathrm{i}$ over time. The shocks have the following properties: the variance is normalized to equal unity, $E\left(¥_{t_{t}}^{\prime}\right)=I, E\left(¥_{t}, ¥_{t+j}\right)=0$, and $\forall j \neq 0$.

In order to identify this model, one can estimate a finite order bivariate VAR

$$
\Delta \mathrm{X}_{\mathrm{t}}=\mathrm{B}_{1} \mathrm{X}_{\mathrm{t}-1}+\ldots+\mathrm{B}_{\mathrm{k}} \Delta \mathrm{X}_{\mathrm{t}-\mathrm{k}}+\mathrm{e}_{\mathrm{t}}
$$

where the maximum lag length $k$ is chosen ${ }^{12}$ such that residuals $e_{t}$, approximate white noise and

$$
E\left(e_{e} e_{t}\right)=\sum=\left[\begin{array}{ll}
11 & 12 \\
21 & 22
\end{array}\right] \text {. }
$$

Since the elements of $\Delta X_{t}$ are stationary, the system can be inverted to obtain the moving average representation:

$$
\Delta \mathrm{X}_{\mathrm{t}}=\mathrm{e}_{\mathrm{t}}+\mathrm{C}_{1} \mathrm{e}_{-1}+\mathrm{C}_{2} \mathrm{e}_{-2} \cdots=\sum_{\mathrm{i}=0}^{\infty} \mathrm{C}_{\mathrm{i}} \mathrm{e}_{\mathrm{t}-\mathrm{i}}=\mathrm{C}(\mathrm{L}) \mathrm{e} .
$$

The contemporaneous relationship between the orthogonal (pure) innovations $¥_{\mathrm{t}}$ and the composite innovations $\mathrm{e}_{\mathrm{t}}$ is

$$
e_{\mathrm{t}}=\mathrm{A}_{0} ¥_{\mathrm{t}} \text {. }
$$

Thus the following relationship exists between the variance-covariance matrices: 
consistently), it imposes one restriction on the matrix of contemporaneous effects, $A_{0}$, which has four elements. Additional restrictions are needed to identify $A_{0}$, so that the orthogonal shocks $¥_{\text {it }}$ can be recovered using equation (5). The traditional method is to pick $A_{0}$ as the Choleski factorization of $\Sigma$, which has been criticized on the grounds that it imposes an arbitrary structure on the orthogonal $¥_{\text {it }}$ sequences. Blanchard and Quah [1989] utilize another way of circumventing the problem of arbitrary identification. This can be seen from the relationship between the matrices of long term effects. If we evaluate the polynomials embedded in equations (1) and (4) at $L=1$, and note the relationship in equation (5):

$$
A(1)=C(1) A_{0}
$$

where $C(1)$ contains known elements. In order to identify the shocks, we impose the following restriction on the long run matrix $A(1)$ : the aggregate supply curve is vertical in the long run. This corresponds to the restriction that $a_{12}(1)=0$ in equation (1). After $A_{0}$ is identified, one can recover the or thogonal shocks using equation (5).

As a final result of estimation we will obtain for each country two series of exogenous shocks: supply shock, $¥_{1, t, p}$, and demand shock, $¥_{2, t, p}$, where $p=$ $1,2 \ldots n$, ( $n$ being the number of countries). Then cor relations of exogenous supply (demand) shocks will be computed among different countries. We later specify the criteria of grouping countries and then compute the correlations among each pair of countries inside the various groups. In assessing the symmetry and asymmetry of correlations of individual shocks between two countries it is assumed that shocks are symmetric if the correlation is positive and significantly different from zero. If the correlation is not statistically different from zero or if there is a negative correlation, such exogenous shocks will be categorized as asymmetric. 
it is possible to think of frameworks other than AD-AS models in which the permanent (supply) and temporary (demand) shock association might break down. Second, as pointed out by M inford [1993, pp. 226-230], what is ideally required are shocks to structural equations, however, what is obtained are decomposed shocks to reduced form equations. ${ }^{13}$ The advantage of the vector-autoregressive (AD-AS) methodology is "that it provides a simple and intuitive method of identifying the underlying macroeconomic disturbances using the closest thing to a consensus model in the macroeconomic literature" 〈Bayoumi and Eichengreen [1994], p. 13〉.

\section{Data and Results}

We used World Bank data sets providing yearly data from 1960 to 1992, for most of the forty countries in our sample. For some countries, due to the lack of data, a shorter span of time [1960-1989] was used. The data used is GDP at market prices in local currency and GDP in constant prices in the local cur rency. Price data was derived by dividing the former by the latter. The exact list of countries and their abbreviations are in Table $1 \mathrm{~A}$ in the appendix. ${ }^{14}$ In addition, this table introduces the basic statistics (mean, standard deviation) for each nation. An interesting fact emerging from the table concerns the low average inflation rate for the French speaking Western African nations. ${ }^{15}$

In order to avoid selection bias an attempt was made to collect data on all

13. According to M inford [1993, pp. 236-237], "The temporary effects reflect transitory supply shocks, fiscal and monetary responses, temporary fiscal transfers (or their absence)...The permanent effects include all supply variables integrated of order one (that is whose first differences are stationary) - such as oil prices, tax rates, public

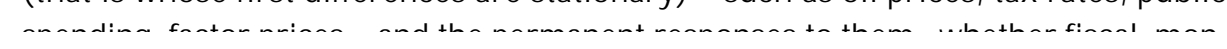


African countries. From the 53 African countries listed in the African Review 1996, however, a few had to be left out because basic data was not available, at least for the years 1960-1989. These countries were Angola, Cape Verde, Comoros, Djibouti, Equatorial Guinea, Eritrea, Guinea, Guinea-Bissau, Liberia, M ozambique, Namibia, São Tome, and Uganda.

The results of the analysis of the data are presented in the following manner. Initially, the pairwise correlations of demand and supply shocks among the CFA franc zone will be presented. These countries have already formed currency unions. These are the Western African M onetary Union, ${ }^{16}$ with the Central Bank for Western African States (BCEAO) as the central bank, ${ }^{17}$ and the Central African Customs Union, ${ }^{18}$ with the Bank for Central African States (BEAC) serving as the central bank.

The correlations obtained for countries of the CFA franc zone can serve as a basis for comparisons with correlations in other regions in Africa. The CFA countries are used as a standard of comparison because they have already achieved a certain degree of currency unification. If it turns out, for example, that demand or supply shocks are less correlated across CFA countries then across some other African regions, then the asymmetric shocks existing in the latter region will probably not represent an insurmountable barrier to attempts at currency unification in the future. While CFA countries will provide an inter-African metric, towards the end of the paper correlations among Western European nations are used as an external (out of Africa) metric in assessing the importance of the symmetry and asymmetry of correlations of permanent and temporary disturbances in Africa.

backed up statistically. Upon independence, central banks were set up in all the B ritish countries and money market institutions were developed in some. This contrasts sharply with the former F rench colonies which have never achieved monetary 
In addition to the above, cor relations of shocks in N orthern, Western and Central, Eastern, and Southern Africa are also calculated and discussed. Finally, as mentioned above, correlations for Western European nations are calculated and discussed.

\section{A. Countries of the CFA Franc Zone}

The results in Tables 1 and 2 show that supply (permanent) shocks are mostly asymmetric across the CFA franc zone countries. However, demand shocks for some countries in Table 1 are symmetric. These results seem to indicate that the CFA franc zone is far from qualifying as an optimum cur rency area. Following Boughton [1993, p. 10] the reason can perhaps be found in "the very small degree of intra-regional trade, some inflexibility of prices and wages, and a wide diversity of incidence of shifts in the terms of trade. The unavailability of the exchange rate as a policy tool has doubtless placed an extra burden on fiscal policies, factor mobility, and support from abroad." However, the higher incidence of symmetric demand shocks probably reflects the ability of the governments, especially in BCEAO areas, to stabilize economic activity, and especially the price level.

\section{B. Correlations in Different African Regions}

\section{Northern Africa}

Table $2 \mathrm{~A}$ shows the results of how shocks affecting Northern Africa are correlated across

Table 1

\section{Correlations of Exogenous Real Supply and Demand Shocks Among} CFA Franc Zone Countries, BCEAO

\begin{tabular}{|l|r|r|r|r|r|r|r|r|}
\hline & CIV & SEN & TGO & BEN & NER & BFA & MRT & $\begin{array}{l}\text { Libya) share sym- } \\
\text { metric demand }\end{array}$ \\
\hline Côte d'Ivoire & - & -0.03 & 0.01 & 0.06 & -0.10 & 0.23 & 0.20 & shocks among each \\
Senegal & -0.03 & - & -0.12 & 0.06 & -0.15 & 0.10 & 0.14 & shor \\
- & $\ldots$ & $\ldots$ & & $\ldots$ & $\ldots$ & $\ldots$ & $\ldots$ & $\ldots$
\end{tabular}

countries. Four

Northern African countries (Algeria, Tunisia, M orocco, lother and the 
Table 2

Correlations of Exogenous Real Supply and Demand Shocks Among CFA Franc Zone Countries, BEAC

\begin{tabular}{|l|c|c|c|c|c|}
\hline & COG & GAB & CAF & TCD & CM R \\
\hline Congo & - & 0.06 & -0.07 & -0.39 & 0.06 \\
Gabon & $\mathbf{0 . 3 7}$ & - & 0.12 & -0.21 & 0.17 \\
Central African Rep. & -0.08 & -0.04 & - & 0.08 & 0.04 \\
Chad & 0.23 & 0.26 & -0.14 & - & 0.00 \\
Cameroon & 0.11 & -0.08 & -0.16 & $\mathbf{0 . 3 3}$ & - \\
\hline
\end{tabular}

N ote: Equatorial Guinea is not included because of non-availability of data. Above the diagonal are the real supply shocks and below the diagonal the demand shocks.

ern and Central African countries ( 12 countries of the CFA franc zone and Nigeria, Ghana and Gambia). Similar to other regions in our investigation only a few countries share symmetric real supply (permanent) shocks among each other, however, there is no group of three countries which would share symmetric permanent shocks among each other. This situation is rather different concerning the demand shocks as is indicated in the table below (Table 3), in which those countries which share the highest number of statistically significant positive correlation are isolated. These countries include six members of the BCEAO area (Niger, Benin, Togo, Côte d'Ivoire, Burkina Faso, Senegal), and three countries of the BEAC area (Gabon, Congo, Central African Republic). Interestingly, the correlations across these two currency unions are for some countries higher than correlations inside their currency area (i.e. Gabon shares symmetric correlations with six countries, of which only one is a member of the same central bank area).

From the set of countries in Table $3 \mathrm{~A}$ it is interestina to note that 
Table 3

Demand Shocks Among Selected Group of Western and Central African Countries

\begin{tabular}{|l|c|c|c|c|c|c|c|c|c|}
\hline & CIV & SEN & TGO & BEN & NER & BFA & COG & GAB & CAF \\
\hline Côte d'Ivoire & - & & & & & & & & \\
Senegal & -0.03 & - & & & & & & & \\
Togo & $\mathbf{0 . 4 9}$ & $\mathbf{0 . 4 5}$ & - & & & & & & \\
Benin & 0.07 & 0.07 & -0.09 & - & & & & & \\
Niger & $\mathbf{0 . 3 9}$ & $\mathbf{0 . 3 2}$ & 0.25 & 0.16 & - & & & & \\
Burkina Faso & $\mathbf{0 . 2 9}$ & $\mathbf{0 . 4 7}$ & $\mathbf{0 . 4 5}$ & 0.05 & $\mathbf{0 . 2 9}$ & - & & & \\
Congo & $\mathbf{0 . 2 9}$ & 0.02 & 0.27 & $\mathbf{0 . 3 1}$ & 0.09 & $\mathbf{0 . 3 2}$ & - & & \\
Gabon & $\mathbf{0 . 4 4}$ & $\mathbf{0 . 5 1}$ & $\mathbf{0 . 3 2}$ & $\mathbf{0 . 3 0}$ & $\mathbf{0 . 3 2}$ & 0.21 & $\mathbf{0 . 3 7}$ & - & \\
C African Rep & $\mathbf{0 . 3 2}$ & 0.03 & $\mathbf{0 . 4 4}$ & $\mathbf{0 . 3 0}$ & 0.14 & 0.04 & -0.08 & -0.04 & - \\
\hline
\end{tabular}

symmetric supply shocks, does share symmetric demand shocks with Chad.

Data in Table 3A show that the correlations of supply and demand shocks of most of the Western and Central African countries with Nigerian supply and demand shocks are not statistically positively different from zero at the $5 \%$ significance level (the only exceptions being Ghana and Gabon for supply shocks and B enin for demand shocks). Nigeria despite its large population and significant oil exports does not seem to be a unifying force around which it is possible to construct an integration scheme in the future.

\section{Eastern Africa}

Similar to the picture in Western and Central Africa, Eastern African countries share almost no symmetric real supply (permanent) shocks. 
positive symmetric demand shock with other countries is M alawi.

\section{Southern Africa}

Table 5A clearly indicates that South Africa, Zimbabwe, Madagascar and $M$ auritius form a group of countries which share among each other high symmetric demand shocks. While South Africa has symmetric demand shocks with almost each countr y, it has no symmetric shocks in real supply. In addition, there were no symmetric supply shocks between South Africa and any of the Western or Central African countries. On the other hand, there is a high correlation of demand (temporary) shocks among South Africa and Zimbabwe, Botswana, Swaziland, M adagascar, and M auritius.

\section{Comparison with Europe}

In Table 6A the correlations of supply and demand shocks for Western Europe are presented in order to compare it with the results from Africa. Western Europe consists in our sample of 17 countries. ${ }^{19}$ Table 5 provides some comparisons of the occurrence of symmetric supply and demand shocks in Western Europe and Africa. Specifically, the number of significant, symmetric, pairwise correlations is reported. In addition, the proportion of all possible correlations which are significant is also reported in percentage form. Table 5 indicates that in terms of supply shocks, there are few significant cor relations in Africa, either in terms of number or percentages,

Table 4

\section{Demand Shocks}

\begin{tabular}{|l|c|c|c|c|c|c|c|c|}
\hline & ZAR & SOM & KEN & TZA & BDI & RWA & MWI & SYC \\
\hline $\begin{array}{l}\text { Zaire } \\
\text { camalin } \\
\text { nos }\end{array}$ & & & & & & & \\
\hline
\end{tabular}


in comparison with Europe and with the core countries of Europe. However, the supply side correlations for BCEAO, Northern Africa, and Western and Central Africa are similar to those achieved among the peripheral countries of Europe and between the core and periphery of Europe. However, one must remember that the relatively high percentage of statistically significant symmetric shocks in these African regions occur only for pairwise combinations of countries. There is not a single group of three or more countries in our African sample that has all possible combinations of correlations among each other statistically significantly different from zero. The situation in this

\section{Table 5}

\section{Summary of the Symmetric Supply and Demand Shocks} in E urope and Africa

\begin{tabular}{|c|l|c|c|c|c|}
\hline \multicolumn{2}{|c|}{} & \multicolumn{2}{|c|}{ Supply Shocks } & \multicolumn{2}{c|}{ Demand Shocks } \\
\cline { 3 - 6 } & $\begin{array}{c}\text { \#of significant } \\
\text { symmetric } \\
\text { correlations }\end{array}$ & $\begin{array}{c}\text { \%from all } \\
\text { possible } \\
\text { correlations }\end{array}$ & $\begin{array}{c}\text { \#of significant } \\
\text { symmetric } \\
\text { correlations }\end{array}$ & $\begin{array}{c}\text { \%from all } \\
\text { possible } \\
\text { correlations }\end{array}$ \\
\hline \multirow{5}{*}{ Europe } & all countries (17) & 34 & 25.0 & 57 & 41.9 \\
\cline { 2 - 6 } & core countries (8) & 20 & 71.5 & 18 & 64.2 \\
\cline { 2 - 6 } & peripheral countries (9) & 4 & 11.1 & 13 & 36.1 \\
\cline { 2 - 6 } & core-periphery & 10 & 13.8 & 26 & 36.1 \\
\hline \multirow{5}{*}{ Africa } & BCEA0 (7) & 3 & 14.3 & 8 & 38.9 \\
\cline { 2 - 6 } & BEAC (5) & 0 & 0.0 & 2 & 20.0 \\
\cline { 2 - 6 } & Northern (5) & 2 & 20.0 & 7 & 70.0 \\
\cline { 2 - 6 } & Eastern (11) & 3 & 5.4 & 7 & 12.7 \\
\cline { 2 - 6 } & Southern (7) & 2 & 9.5 & 8 & 38.1 \\
\cline { 2 - 6 } & Western and Central (15) & 12 & 11.4 & 26 & 24.7 \\
\hline
\end{tabular}


respect is rather different in Europe, as Table 6 shows. From the eight countries of the core, six have all possible supply shock correlations significantly different from zero.

With respect to demand shock correlations, symmetry is more widespread both in Europe and Africa, although still less so in Africa. However, in the North African region the percentage of symmetric demand shocks is comparable to that within the European core, and in BCEAO and Southern Africa with the European periphery.

This leads us to our last question: why then are the correlations of supply and to some extent also of demand shocks so low in Africa? The literature provides us with different illustrative answers. The main reason for the prevailing asymmetric permanent shocks in Africa is probably the character of African trade. Intra-African trade accounts only for a small proportion of the total African trade. M undell [1972, p. 27] argues that "the African nations appear to lack ... the complementarity resource conditions that usually promote trade; this lack of complementarity has led to duplication of the production pattern and a channeling of trade toward the former mother country." In this spirit M ulat [1991, p. 34] raises the question of the underdeveloped nature of the transportation and communication network in Africa and concludes that "the issue of intra-African trade expansion is intertwined with the wider issues of economic growth and production restructuring in Africa." Similarly Cobham and Robson argue that "intraregional trade inten-

Table 6

Correlations of Supply Shocks in Core European Countries

\begin{tabular}{|c|c|c|c|c|c|c|c|c|}
\hline & $\mathrm{GE}$ & $F R$ & NE & $B E$ & SW & $A U$ & LU & $\mathrm{DE}$ \\
\hline Germany & - & 0.51 & $\begin{array}{l}0.56 \\
n \ln \end{array}$ & $\begin{array}{l}0.48 \\
n, 15\end{array}$ & $\begin{array}{l}0.32 \\
n, 11\end{array}$ & $\begin{array}{l}0.48 \\
n, 1\end{array}$ & $\begin{array}{l}0.48 \\
n \supset 5\end{array}$ & $\begin{array}{l}0.44 \\
n, 17\end{array}$ \\
\hline
\end{tabular}


sity is relatively low and external trade dependence is correspondingly high." In contrast, intra-EU trade represents approximately half of their total trade. Thus, idiosyncratic supply and demand shocks, problems with trade patterns, as well as a low degree of product diversification in most of African countries, lead us to conclude that there is still room for flexible exchange rates to cushion the African countries from the negative effects of outside shocks. This leads to the overall implication that the scope for currency union at this time is quite limited for most of Africa.

\section{Summary and Conclusions}

In this short paper an attempt has been made to empirically determine whether or not temporary and permanent shocks influence various African nations in a symmetric or asymmetric manner. If these shocks were found to be symmetric in nature among a number of nations, this would be strong evidence in favor of a currency union among these nations or, more generally, the desirability of maintaining fixed exchange rates among this set of nations. Alternatively, if the shocks were found to be asymmetric in nature, this would be strong evidence that a currency union is not desirable or, more generally, the desirability of maintaining flexible exchange rates.

There was some degree of symmetry found for demand or temporary shocks. In particular there were three groups of nations which had a relatively high degree of demand shock symmetry. These were: Egypt, Algeria, M orocco, Libya, and Tunisia; Niger, Benin, Togo, Côte d'I voire, Burkina Faso, Gabon, Congo, Central African Republic, and Senegal; South Africa, Zimbabwe, $M$ adagascar, and $M$ auritius. The evidence concerning symmetric supply (permanent) shocks is much weaker. There are no groups of more than three countries which share symmetric supply shocks. The over- 


\section{Reference}

Africa Review [1996], The Economic and Business Report, Kogan Page and

Walden Publishing, London.

Bayoumi, Tamin, and Eichengreen, Barry [1993], "Shocking Aspects of

European M onetary Unification," in Torres and Giavazzi, eds., Adjust ment and Growth in the European M onetary Union, Cambridge, Cambridge University Press.

Bayoumi, Tamin, and Eichengreen, Barry [1992], "Shocking Aspects of

European M onetary Unification," NBE R Working Paper \#3949, January. B ayoumi, Tamin, and Eichengreen, Barry [1994], "One M oney or M any?

Analyzing the Prospects for M onetary Unification in Various Parts of

Table 1A

Basic Statistics of Real Output and Price Deflator

\begin{tabular}{|c|c|c|c|c|c|}
\hline \multirow[t]{2}{*}{ Country } & \multirow{2}{*}{$\begin{array}{l}\text { Country } \\
\text { Code }\end{array}$} & \multicolumn{2}{|c|}{$\begin{array}{c}\text { Real Output } \\
\text { (variable in log first difference) }\end{array}$} & \multicolumn{2}{|c|}{$\begin{array}{c}\text { Price Level } \\
\text { (variable in log first difference) }\end{array}$} \\
\hline & & M ean & St. Deviation & M ean & St. Deviation \\
\hline Algeria & DZA & 0.041 & 0.085 & 0.099 & 0.103 \\
\hline Egypt & $E G Y$ & 0.052 & 0.034 & 0.084 & 0.061 \\
\hline Tunisia & TUN & 0.053 & 0.037 & 0.064 & 0.047 \\
\hline M orocco & MAR & 0.045 & 0.040 & 0.056 & 0.045 \\
\hline Libya & LBY & 0.056 & 0.150 & 0.081 & 0.159 \\
\hline Nigeria & NGA & 0.034 & 0.083 & 0.130 & 0.134 \\
\hline Niger & NER & 0.009 & 0.072 & 0.043 & 0.080 \\
\hline Chad & TCD & 0.016 & 0.076 & 0.041 & 0.066 \\
\hline Benin & BEN & 0.026 & 0.037 & 0.048 & 0.051 \\
\hline Togo & TGO & 0.035 & 0.058 & 0.048 & 0.082 \\
\hline Ghana & $\mathrm{GHA}$ & 0.019 & 0.050 & 0.241 & 0.184 \\
\hline Côte d'Ivoire & CIV & 0.046 & 0.064 & 0.046 & 0.084 \\
\hline Sierra Leone & SLE & 0.025 & 0.083 & 0.233 & 0.250 \\
\hline Rurkina Facn & RF $\Delta$ & $\cap \cap 3)$ & $\cap \cap 3 \cap$ & $\cap \cap \Delta 7$ & $\cap \cap \Delta \kappa$ \\
\hline
\end{tabular}


Table 1A (cont'd)

Basic Statistics of Real Output and Price Deflator

\begin{tabular}{|l|l|l|c|c|c|}
\hline \multirow{2}{*}{ Country } & \multirow{2}{*}{$\begin{array}{c}\text { Country } \\
\text { Code }\end{array}$} & \multicolumn{2}{c|}{$\begin{array}{c}\text { Real Output } \\
\text { (variable in log first difference) }\end{array}$} & \multicolumn{2}{c|}{$\begin{array}{c}\text { Price Level } \\
\text { (variable in log first difference) }\end{array}$} \\
\cline { 3 - 6 } & & M ean & St. Deviation & M ean & St. Deviation \\
\hline Zaire & ZAR & 0.012 & 0.056 & 0.333 & 0.222 \\
Sudan & SDN & 0.022 & 0.068 & 0.198 & 0.174 \\
Ethiopia & ETH & 0.024 & 0.037 & 0.031 & 0.032 \\
Somalia & SOM & 0.023 & 0.085 & 0.223 & 0.264 \\
Kenya & KEN & 0.055 & 0.047 & 0.068 & 0.062 \\
Tanzania & TZA & 0.040 & 0.028 & 0.126 & 0.098 \\
Burundi & BDI & 0.050 & 0.063 & 0.050 & 0.085 \\
M alawi & M WI & 0.038 & 0.048 & 0.089 & 0.063 \\
Rwanda & RWA & 0.033 & 0.056 & 0.080 & 0.128 \\
Zambia & ZM B & 0.019 & 0.048 & 0.188 & 0.234 \\
Seychelles & SYC & 0.047 & 0.054 & 0.068 & 0.070 \\
South Africa & ZAF & 0.031 & 0.028 & 0.100 & 0.050 \\
Zimbabwe & ZWE & 0.036 & 0.056 & 0.087 & 0.087 \\
Botswana & BWA & 0.010 & 0.068 & 0.080 & 0.078 \\
Lesotho & LSO & 0.052 & 0.077 & 0.086 & 0.075 \\
Swaziland & SWZ & 0.057 & 0.062 & 0.084 & 0.053 \\
M adagascar & MDG & 0.011 & 0.037 & 0.100 & 0.068 \\
M auritius & M US & 0.041 & 0.057 & 0.085 & 0.091 \\
\hline
\end{tabular}

Note: Price level (GDP deflator) calculated from the real and nominal output data for 1960-1992. For M ali, Libya, Zaire, Zambia, and Sierra Leone shorter spans of time were used.

\section{Table 2A}

\section{Correlations of Exogenous Real Supply and Demand Shocks} in North African Region

\begin{tabular}{|l|c|c|c|c|c|}
\hline & EGY & TUN & DZA & MAR & LBY \\
\hline$-\ldots$
\end{tabular}




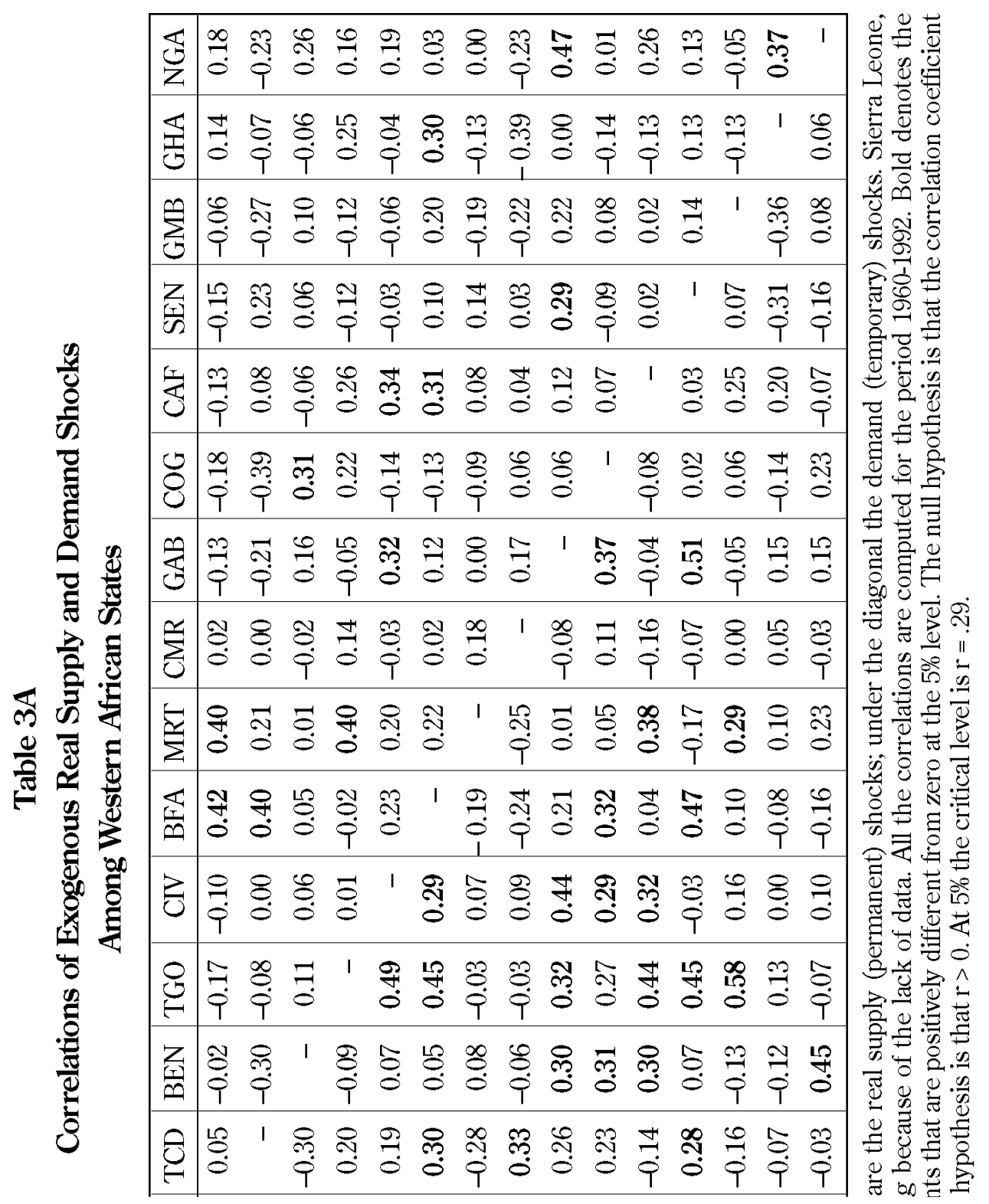


Table 4A

Correlations of Exogenous Real Supply and Demand Shocks

Among Eastern African States

\begin{tabular}{|l|r|r|r|r|r|r|r|r|r|r|r|}
\hline & ZAR & SDN & ETH & SOM & KEN & TZA & BDI & RWA & M WI & SYC & ZM B \\
\hline Zaire & - & 0.39 & 0.09 & -0.32 & 0.22 & 0.25 & 0.17 & -0.11 & -0.09 & -0.15 & -0.14 \\
Sudan & -0.05 & - & 0.13 & -0.04 & -0.35 & -0.24 & 0.06 & -0.02 & -0.23 & -0.25 & -0.16 \\
Ethiopia & -0.37 & -0.14 & - & & 0.22 & 0.10 & 0.12 & 0.10 & 0.22 & -0.02 & -0.04 \\
Somalia & 0.33 & -0.20 & 0.21 & - & 0.10 & 0.04 & 0.17 & 0.03 & 0.03 & 0.23 & 0.27 \\
Kenya & -0.21 & -0.07 & 0.23 & -0.07 & - & 0.02 & 0.11 & 0.03 & 0.57 & 0.24 & -0.24 \\
Tanzania & 0.00 & 0.06 & 0.07 & -0.19 & 0.24 & - & 0.00 & -0.18 & -0.03 & 0.32 & -0.07 \\
Burundi & 0.10 & -0.16 & 0.27 & 0.09 & 0.18 & -0.18 & - & 0.01 & 0.06 & 0.30 & 0.12 \\
Rwanda & -0.12 & -0.05 & 0.07 & -0.18 & 0.02 & 0.09 & 0.41 & - & 0.06 & 0.12 & 0.01 \\
Malawi & $\mathbf{0 . 3 0}$ & -0.11 & 0.25 & $\mathbf{0 . 3 3}$ & $\mathbf{0 . 3 1}$ & 0.28 & 0.09 & -0.11 & - & 0.26 & -0.14 \\
Seychelles & 0.00 & -0.02 & 0.04 & -0.15 & $\mathbf{0 . 4 7}$ & 0.10 & $\mathbf{0 . 2 9}$ & 0.25 & 0.00 & - & 0.28 \\
Zambia & 0.13 & -0.16 & -0.04 & 0.23 & 0.05 & -0.03 & -0.29 & -0.62 & 0.05 & -0.19 & - \\
\hline
\end{tabular}

Note: Above the diagonal are the real supply (permanent) shocks; under the diagonal the demand (temporary) shocks. Correlations with Zaire and Zambia are for the period 1960-1989, otherwise 1960-1992. Bold denotes the correlation coefficients that are positively different from zero at the $5 \%$ level. The null hypothesis is that the correlation coefficient $r=0$, the alternative hypothesis is that $r>0$. At $5 \%$ the critical level is $r=.29$.

\section{Table 5A}

Correlations of Exogenous Real Supply and Demand Shocks Among Southern African States

\begin{tabular}{|l|c|c|c|c|r|r|r|}
\hline & ZAF & ZWE & BWA & LSO & SWZ & MDG & M US \\
\hline South Africa & - & 0.26 & 0.03 & 0.22 & 0.05 & 0.04 & -0.18 \\
Zimbabwe & $\mathbf{0 . 3 1}$ & - & 0.03 & 0.01 & 0.11 & -0.01 & 0.02 \\
Botswana & $\mathbf{0 . 3 3}$ & 0.11 & - & $\mathbf{0 . 3 1}$ & 0.13 & -0.15 & $\mathbf{0 . 3 7}$ \\
Lesotho & -0.03 & 0.06 & 0.22 & - & -0.04 & -0.03 & 0.16
\end{tabular}




\begin{tabular}{|c|c|c|c|}
\hline \multirow{15}{*}{ 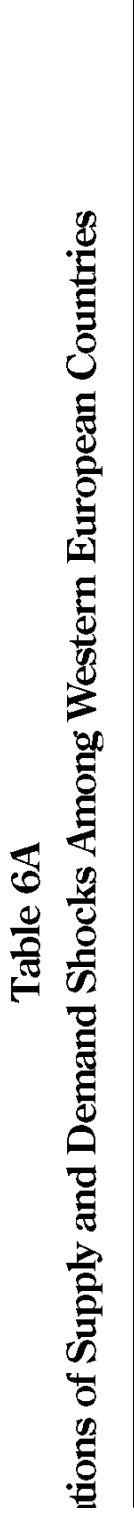 } & $z$ & 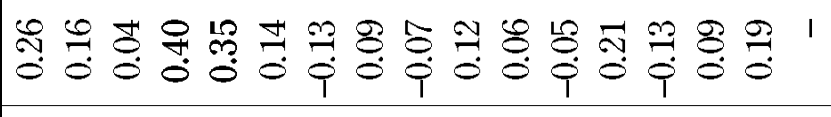 & \multirow{15}{*}{ 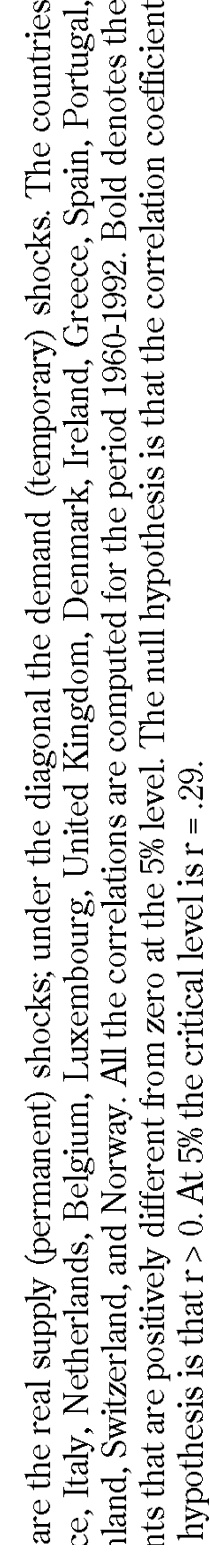 } \\
\hline & 3 & 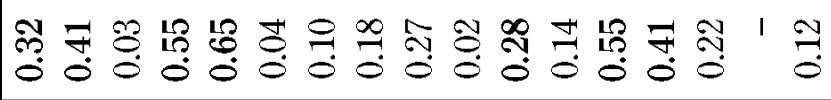 & \\
\hline & & 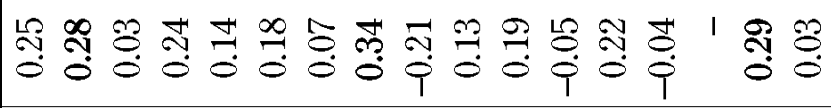 & \\
\hline & $\frac{1}{\sqrt{2}}$ & 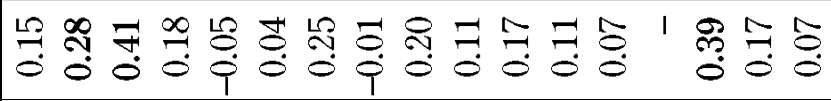 & \\
\hline & $\vec{z}$ & 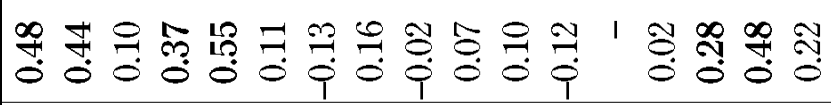 & \\
\hline & $£$ & 붕융융융 & \\
\hline & के & : & \\
\hline & & 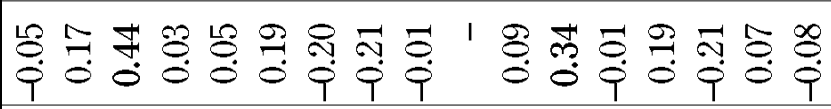 & \\
\hline & $\cong$ & 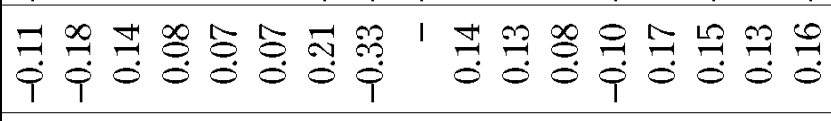 & \\
\hline & & 军 声 & \\
\hline & & 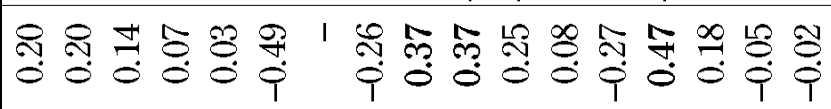 & \\
\hline & & 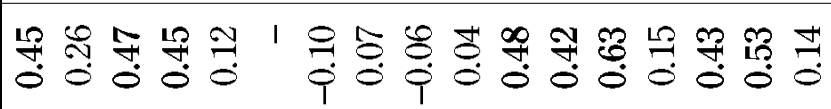 & \\
\hline & & 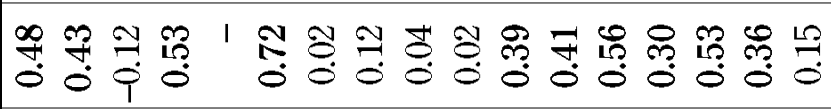 & \\
\hline & & 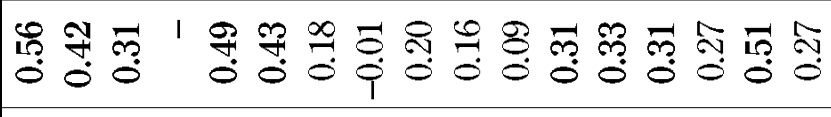 & \\
\hline & & $\bar{x}$ & \\
\hline
\end{tabular}


the World," Princeton Studies in International Finance, No. 76, September.

Blanchard, Olivier J. and Quah, Danny [1989], "The Dynamic Effects of Aggregate Demand and Supply Disturbances," American Economic Review, September; pp. 655-673.

Bofinger, Peter, [1994], "Is Europe an Optimum Currency Area?," in Steinherr, Alfred, ed., 30 Years of E uropean M onetary Integration from the Werner Plan to EMU.

Chamie, Nick, DeSerres, Alain, and Lalonde René [1994], "Optimum Currency Areas and Shock Asymmetry, A Comparison of Europe and the United States," Bank of Canada, Working Paper 94-1.

Cobham, David and Peter Robson [1994], "M onetary Integration in Africa: A Deliberately European Perspective," World Development, Vol. 22, No. 3; pp. 285-299.

Devarajan, Shantayanan and Jaime de M elo [1987], "Evaluating Participation in African M onetary Union: A Statistical Analysis of the CFA Zones," World Development; pp. 483-496.

de Grauwe, Paul [1994], The E conomics of M onetary Integration, Oxford University Press.

Diouf, M akhtar [1994], "Scenarios for African Economic Integration," Futures, 9; pp. 993-998.

Helliwell, John F. and Tim Padmore [1985], "E mpirical Studies of M acroeconomic Interdependence," in $\mathrm{H}$ andbook of International E conomi cs, vo. II, edited by R. W. J ones and P. B. Kenen, Elsevier Science Publishers B.V.

International M onetary Fund [1994], World E conomic Outlook, October.

Ishiyama, Yoshihide, [1975], "The Theory of Optimum Currency Areas: A Survey," Staff Papers, International M onetary Fund, Washington, Vol. 
Machlup, Fritz, [1977], A History of Thought on Economic Integration, Columbia University Press.

M asson, Paul R. and Taylor, Mark P. [1994], "Optimal Currency Areas: A Fresh Look at the Traditional Criteria," in Siklos, ed. Varieties of M one tary Reforms: Lessons and Experiences on the Road to M onetary Union, Kluwer Academic Publishers.

M cKinnon, Ronald I. [1963], "Optimum Currency Area," LIII, 4, American E conomic Review, September; pp. 717-725.

McKinnon, Ronald I. [1979], M oney in International Exchange, Oxford, Oxford University Press.

Minford, P., [1993], "Discussion of Bayoumi and Eichengreen," in Torres and Giavazzi, eds., Adjustment and Growth in the European Monetary Union, Cambridge, Cambridge University Press.

M ulat, Teshome [1991], "Commodity Trade Flows B etween African Countries: D evelopments, Problems, and Prospects," in Oliver S. Saasa, ed., Joining the Future, Economic Integration and Cooperation in Africa, African Centre for Technology Studies, Nairobi, Kenya.

M undell, Robert A., [1961], "A Theory of O ptimum Currency Areas," Amer ican Economic Review; pp. 657-665.

M undell, Robert A. [1972], "African Trade, Politics and M oney," in Afrique et Intégration M onétaire," ed. by Rodrique Tremblay, Les Éditions HRW.

Nelson, Charles R. and Charles L. Plosser [1982], "Trends and Random Walks in M acroeconomic Time Series," Journal of M onetary E conom ics, September; 10, pp. 139-162.

Tavlas, George S., [1993], "The 'N ew' Theory of Optimum Currency Areas," The World Economy, Vol. 16; pp. 663-685.

Vahid, F. and Engle, R. F., [1993], "Common Trends and Common Cycles," 
